\title{
APLICAÇÃO DA LEI N 13.019/2014 PELOS ESTADOS E MUNICÍPIOS: REFLEXÕES A PARTIR DE SUA REGULAMENTAÇÃO NO ESTADO DO PARANÁ.
}

\section{APPLYING THE FEDERAL LAW N. 13.019/2014 BY THE STATES AND CITIES: REFLECTIONS OUT OF ITS REGULATION BY THE STATE OF PARANÁ.}

\author{
${ }^{1}$ Guilherme Henrique Hamada
}

\section{RESUMO}

Com a entrada em vigor da Lei $\mathrm{n}^{\circ} 13.019 / 2014$ no início de 2016, surgiram dúvidas sobre a obrigatoriedade de sua aplicação por Estados e Municípios e como se harmonizaria com a legislação sobre licitações e contratos existente. Através do método analítico-dedutivo o presente artigo busca sugerir, a partir da legislação paranaense e verificando a evolução das parcerias, sua competência legislativa e seu âmbito de aplicação, uma forma de cumprir a nova lei harmonizando-a com a regulamentação dos convênios que instrumentalizam as parcerias entre a Administração Pública e as entidades do terceiro setor.

Palavras-chave: Direito administrativo, Organização da sociedade civil, Parceria, Eficiência, Políticas públicas

\begin{abstract}
After the Federal Law no 13.014/2014 became effective, States and Cities questioned if they have to respect it and how they would harmonize it with the existing legislation regarding administrative contracts. Through the analytic-deductive method, the present paper seeks to suggest, using the laws of the State of Parana as basis and verifying the evolution of the partnerships, legislative powers and its coverage, a way to enforce the new law along with the existing regulation for the partnerships of the Public Administration and the third sector entities.
\end{abstract}

Keyword: Administrative law, Civil society organizations, Partnership, Eficiency, Public policies

\footnotetext{
${ }^{1}$ Mestrando em Direito Econômico e Socioambiental pela Pontifícia Universidade Católica do Paraná - PUC/PR, Paraná (Brasil). E-mail: guilherme.hamada@yahoo.com.br
} 


\section{INTRODUÇÃO}

Com a entrada em vigor da Lei no 13.019/2014 no início de 2016, sua aplicação passou a exigir uma reflexão profunda pelos Estados e Municípios. Até sua edição, as parcerias da Administração Pública com o terceiro setor, para consecução de objetivos de interesse público, eram formalizadas através de convênios.

Aos convênios era aplicado, por determinação do art. 116 da Lei no 8.666/1993, o mesmo regime jurídico das demais contratações do Estado, excetuando-se situações consideradas como incompatíveis com sua natureza. No âmbito federal, a regulamentação dos convênios era objeto de divergências doutrinárias em situações como, por exemplo, a necessidade de realização de processo seletivo para escolha da entidade parceira.

Para os Estados e Municípios a questão era ainda mais controversa, vez que a competência privativa da União para editar normas gerais sobre licitações e contratos decorre do inc. XXVII do art. 22 da Constituição. Questionava-se se a Lei Federal de Licitações era de conteúdo nacional e se as regras aplicáveis aos convênios da União deveriam ser observadas pelos Estados e Municípios.

Com o novo marco das parcerias, que excluiu a aplicação da Lei $\mathrm{n}^{\circ}$ 8.666/1993 na relação entre Administração Pública com o terceiro setor, as dúvidas então existentes voltaram a confundir administradores públicos e particulares. Questões relacionadas à competência para legislar sobre parcerias e de como devem ser harmonizadas as novas regras com a legislação já existente nos entes federativos, causam insegurança para a Administração Pública e para os particulares parceiros.

A presente pesquisa busca, através do método analítico-dedutivo, sugerir, com base no exemplo da legislação paranaense sobre a matéria, como os Estados e Municípios devem aplicar a Lei 13.019/2014. Para alcançar uma resposta, relembra o contexto da evolução das parcerias a partir da década de 1990, analisa o âmbito de aplicação da nova lei e revisa a competência para regulamentar os acordos. Ao final, descreve a regulamentação das parcerias pelo Estado do Paraná e sugere uma forma de interpretação da norma no âmbito paranaense e para os demais Estados e Municípios. 


\section{AS PARCERIAS DA ADMinistraÇão PÚBliCA COM O TERCEIRO SETOR}

A crescente complexidade da organização do Estado e o surgimento de novos interesses exigiu um processo de modernização e de reformulação dos instrumentos administrativos. (OLIVEIRA, 2015). Em tempos recentes, o individual e o particular foram exaltados pela crítica ao panorama intervencionista do Estado. Prega-se a "desestatização", a "desregulamentação" e a "desumanização" como se a atuação direta do Estado fosse algo ruim e a transferência de atividades à iniciativa privada algo natural (GABARDO, 2003).

Defende-se a aproximação do Estado com o terceiro setor, denominação dos entes que não são o Estado (primeiro setor) nem pertencem ao conjunto daqueles que atuam com finalidade lucrativa e possuem personalidade privada (segundo setor), mas que mantém vínculos colaborativos com o Poder Público para realização de atividades de interesse público (MEDAUAR, 2015). ${ }^{1}$ Como ensina di Pietro (2012), a substituição de uma única estrutura autossuficiente por unidades autônomas de mútua colaboração também tem sido aplicada no campo empresarial, com a supressão de grandes empresas autossuficientes por sistemas de cooperação entre empresas especializadas, e no campo internacional, com a formação de organismos que sintetizam os objetivos de diversos países parceiros. "As ideias de parceria e colaboração dominam todos os setores, com reflexos inevitáveis no âmbito do Direito" (DI PIETRO, 2012, p. 2).

Justen Filho (2014, p. 128) explica que "No passado, reputava-se que a atividade administrativa pública era monopolizada pelo Estado. Essa concepção vem sendo alterada, com a perspectiva de que a função administrativa é desempenhada também por entidades não estatais". Houve uma mudança primordialmente ideológica, que privilegiou a redução do papel do Estado executor em prol do Estado fomentador. Passou-se a defender a participação da sociedade na Administração Pública e a diminuição do Estado. Troca-se a atuação estatal rígida, com atos unilaterais e verticalizados, pelas formas de atuação mais flexíveis e eficientes da iniciativa privada (DI PIETRO, 2012).

\footnotetext{
${ }^{1}$ Oliveira (2015, p. 61) denomina de: "10 Setor: Estado (Administração Pública Direta e Administração Pública Indireta); 2osetor: mercado (concessionárias e permissionárias de serviços públicos); 3o setor: sociedade civil (Serviços Sociais Autonomos - Sistema 'S', Organizações Sociais - 'OS', Organizações da Sociedade Civil de Interesse Público 'OSCIPs' etc.)."
} 
Há, na atualidade, tendência de busca por uma atuação consensual, entre Estado e particulares, para exercício da atividade administrativa (JUSTEN FILHO, 2014). Buscando possibilitar a atuação do terceiro setor na consecução dos objetivos do Estado, novos instrumentos jurídicos têm sido criados para regulamentar as relações público-privadas. Estes vínculos, que dependem de previsão legal, são denominados genericamente de parcerias (MEDAUAR, 2015).

As parcerias não buscam satisfazer uma necessidade direta e imediata do Estado ou dos particulares, apenas regulam condutas que produzirão efeitos na comunidade (JUSTEN FILHO, 2014). Também não implicam na descentralização de serviço público, pois podem envolver serviços sociais não exclusivos do Estado, que atua como fomentador da atividade, como são os casos das parcerias com o terceiro setor (DI PIETRO, 2012).

Diante da constante criação de novos institutos, não é possível estabelecer um rol taxativo das formas de parceria existentes no Brasil (JUSTEN FILHO, 2014). Trata-se de tema novo no direito brasileiro, disciplinado genericamente através de leis esparsas que variam conforme os interesses da Administração Pública, e cuja inspiração vem, comumente, de modelos estrangeiros que não se adaptam ao direito positivo pátrio (DI PIETRO, 2012).

Sob a alegação de eficiência e de que a iniciativa privada produz bons resultados, parcerias são firmadas sem que se saiba exatamente o maior beneficiário do acordo: o Estado, os usuários de serviços públicos ou até mesmo os dirigentes das entidades. Há casos em que se confundem receitas, sedes administrativas, recursos humanos e recursos materiais do Estado e dos particulares. Existem, inclusive, entidades cuja sobrevivência depende do financiamento estatal (DI PIETRO, 2012).

Sem desprezar a importância da eficiência, é sedutor o argumento de que uma administração eficiente poderá ser alcançada mais facilmente através da colaboração da sociedade civil. Dentre as facilidades que os particulares possuem em face da Administração Pública, apenas para exemplificar, encontra-se a celebração de contratos. Enquanto os particulares possuem ampla liberdade de atuação, o Poder Público deve obedecer a rígidos procedimentos preestabelecidos (MELLO, 2012).

Ou seja, poderia se pensar que o regime de direito público dificultaria a consecução dos objetivos do Estado em comparação ao regime de direito privado. Acredita-se no mito neoliberal da eficácia como se o intervencionismo pregado pelo Estado de bem-estar social, e não a concreta ineficiência do Estado Liberal, fosse o responsável pelos problemas da atuação do Poder Público (GABARDO, 2003). O terceiro setor, cujo regime jurídico é mais flexível do 
que àquele ao qual estão submetidas as entidades da Administração Pública, surge como alternativa para aplicação do modelo gerencial neoliberal pelo Poder Público (SOUSA, 2015).

Entretanto, nem sempre a celebração de parcerias garantirá a eficiência da atuação estatal, nem evitará interesses escusos do Poder Público e dos particulares colaboradores. A solução dos problemas sociais não depende apenas da cooperação com entidades privadas, e existem atividades que, por envolverem definições políticas dos rumos a serem seguidos pelo país, são essencialmente estatais (JUSTEN FILHO, 2014).

Como pontua Justen Filho (2014, p. 131), A transferência de atividades ou responsabilidades estatais só será legítima se imbuída de rígida regulamentação:

Deve-se ter em vista que a legitimação jurídica da atuação dos particulares para o desempenho de atividades relevantes para a realização dos direitos fundamentais não equivale à ausência de limites normativos ou de controle estatais. A redução da intervenção direta do Estado é acompanhada da ampliação do controle normativo sobre os particulares - de modo a se impor ao particular a realização dos valores e o atingimento dos fins buscados pela comunidade.

Em geral, as parcerias da Administração Pública são formalizadas através de convênio. Convênios são acordos entre órgãos públicos, ou entre o Poder Público e entidades privadas, em regime de mútua cooperação (MEDAUAR, 2015). Os interesses das partes são paralelos e comuns na busca por determinado objetivo, que deve ser de interesse público (CARVALHO FILHO, 2012).

Para que se mantenham legítimas as parcerias do Estado com os particulares diante da tendência de aumento das hipóteses e modelos de parceria buscados pela Administração Pública, a mera utilização de convênio, como hipótese geral, não se mostra suficiente para legitimar o acordo de vontades. Não se trata, portanto, de criar novas formas de parcerias, mas sim de impor limites normativos e de implementar novas formas de controle estatal sobre a cooperação desejada e por vezes já existente, conferindo segurança jurídica à Administração Pública e ao particular.

Se a ideologia neoliberal será implementada, ao menos para terceirização da atuação estatal em prol do interesse público, buscando-se a eficiência da Administração Pública, e se essas parcerias dependem de instrumentos jurídicos para serem concretizadas, devem estar claras as regras que o administrador e os particulares deverão seguir. Um sistema normativo em 
que seja possível identificar o âmbito de aplicação da norma permite que o interesse público, finalidade das parcerias celebradas, prevaleça em face dos interesses individuais.

\section{3 ÂMBITO DE APLICAÇÃO DA LEI Nº 13.019/2014}

Embora tenha sido "apelidada" de novo marco regulatório das parcerias entre a Administração Pública e as Organizações da Sociedade Civil (OSC), a Lei no 13.019/2014 é, para Garcia e Castro (2014), apenas um marco histórico, cujo intuito foi o de coibir as irregularidades e de trazer maior transparência à atuação das OSC. Até então a relação públicoprivada era regulada por normas esparsas, existindo muitas lacunas que causavam insegurança jurídica tanto ao Poder Público como às OSC (OLIVEIRA, 2014).

É preciso destacar, entretanto, que a nova lei não esgota o regramento das parcerias entre o Estado e o terceiro setor, nem mesmo em relação às próprias OSC, haja vista o rol de hipóteses expressamente afastadas das exigências da norma em seu art. $3^{\circ}$. Situações específicas, como a complementariedade do Sistema Único de Saúde pelo setor privado, também não se enquadram ao novo regramento. Tamanhas são as especificidades de algumas parcerias previstas por outras normas e até pela Constituição (como é o caso das parcerias envolvendo o Sistema Único de Saúde), que se torna inviável submetê-las a um regime geral (SANTOS, 2015).

Portanto, para que seja possível delimitar o âmbito de aplicação do novo marco das parcerias pelos Estados e Municípios é preciso compreender o histórico de criação da lei, definir quem são os destinatários do novo preceito e verificar como era regulamentada a relação jurídica entre as OSC e a Administração Pública antes da entrada em vigor da norma.

Foi no âmbito da reforma gerencial promovida na década de 1990 que a atuação do terceiro setor, em parceria com o Estado, foi impulsionada no Brasil. Já existiam normas que tratavam timidamente do tema, como a Lei $n^{\circ}$ 91/1935, mas as reduções orçamentárias aliadas à insuficiência na prestação de serviços públicos previstos na Constituição justificaram a proposta pela busca de eficiência pós Carta Cidadã. Em razão da dificuldade de aumentar a autonomia da Administração Pública, optou-se por um regime mais flexível através da iniciativa privada (SOUSA, 2015).

Vieram, inicialmente, a Lei $\mathrm{n}^{\mathrm{o}}$ 9.637/1998, oriunda das Medidas Provisórias $\mathrm{n}^{\circ} 1.591 / 1995$ e 1.648-7/1998, e a Lei $\mathrm{n}^{\circ}$ 9.790/1999. A primeira regulamentou a participação das Organizações Sociais (OS), enquanto a segunda tratou das Organizações da Sociedade Civil de Interesse Público (OSCIP) (SOUSA, 2015). Ambas autorizam pessoas jurídicas de direito 
privado a receberem recurso públicos, com a diferença que as OS gerem patrimônio que continua público e as OSCIP são auxiliadas pela Administração Pública (COPOLA, 2014).

As OSCIP não caracterizam uma espécie societária autônoma. São pessoas jurídicas de direito privado sem finalidade lucrativa, constituídas sob a forma de fundação ou de associação civil (JUSTEN FILHO, 2014). Trata-se de qualificação atribuída pelo Poder Público a todas as pessoas jurídicas que preencherem os requisitos da Lei n 9.790/1999 (MELLO, 2015).

Diferenciam-se das OS por não exigirem a participação de membros indicados pelo Poder Público na sua administração e pela desnecessidade de pactuação mediante contrato de gestão com o Estado (JUSTEN FILHO, 2014). Divergem, ainda, sobre a necessidade de prévia existência para obtenção da qualificação. Para ser uma OSCIP é essencial a prévia existência da entidade (art. $1^{\circ}$ da Lei $\left.{ }^{\circ} 9.790 / 1999\right)$ ), enquanto as OS podem ser criadas especificamente para celebração do contrato de gestão com a Administração Pública, dependendo apenas do juízo de conveniência e oportunidade do administrador (COPOLA, 2014).

Portanto, enquanto as OS administram recursos públicos através do contrato de gestão, as OSCIP recebem recursos públicos mediante parceria. Estas parcerias, sem um instrumento específico, eram celebradas através de convênios (MARTINS e SILVA, 2014). Agora, os termos de parceria das OSCIP estão regulamentados pela Lei $\mathrm{n}^{\mathrm{o}}$ 13.019/2014 (NOHARA, 2015).

A definição de OSC, para o novo marco regulatório, engloba as OSCIP, que passaram a ser uma espécie sua. Todavia, continuam válidas as disposições da Lei n 9.790/1999, alterada expressamente pela nova lei, que regulamentou a forma como ocorrerão as parcerias até então realizadas sob o aspecto amplo dos convênios.

Reconhecido como um mecanismo eficiente de descentralização da execução de políticas públicas, a abrangência dos convênios permitiu seu desvirtuamento na praxe administrativa, como sua utilização em substituição aos contratos administrativos, submetidos a procedimentos mais rígidos (MARTINS e SILVA, 2014). Como afirma Ribeiro (2015, p. 95) "Na prática, havia aqui uma liberdade de formas para celebrar ajustes entre entidades do Terceiro Setor e o Poder Público [...]”. Esta amplitude foi melhor disciplinada com a substituição dos convênios pelos termos de colaboração ou de fomento.

Recorde-se que a origem da Lei $n^{\circ}$ 13.019/2014 está na Comissão Parlamentar de Inquérito das Organizações Não Governamentais $(\mathrm{ONG}),{ }^{2}$ que apresentou ao congresso o Projeto de Lei $n^{\circ}$ 07/2003, cujo objetivo era aperfeiçoar os instrumentos de parceria (AKEMI, 
2015). Foi a investigação de problemas nos procedimentos de escolha e fiscalização das parcerias firmadas com o terceiro setor que serviu de justificativa para necessidade de maior regulamentação. Como afirmam Guerra e Guerra (2015, p. 48) sobre o regime jurídico anterior à nova lei:

\begin{abstract}
A insegurança jurídica apresenta-se latente no que toca à matéria das organizações da sociedade civil, notadamente em face da ausência de legislação específica, visto que as leis vigentes são imprecisas e insuficientes, gerando interpretações e analogias distintas, além da questão referente à ineficiência do controle, responsável pela grave situação de fraudes e desvios verificados nos últimos anos.
\end{abstract}

Afasta-se a insegurança jurídica e busca-se ampliar o controle e a fiscalização das parcerias voluntárias (MARTINS, 2015). Suprime-se o regime jurídico estabelecido por normas esparsas e infra legais, como o Decreto $n^{\circ}$ 6.170/2007, responsável pela primeira menção ao termo OSC. Essas normas passarão a ser aplicadas apenas naquilo que não contrariar o novo marco e até que a União edite nova regulamentação (BELÉM, 2014).

Amplia-se, ainda, o rol de entidades que podem se tornar parceiras do Poder Público, posto que a Lei ${ }^{\circ}$ 13.019/2014 não restringe sua aplicação às OSCIP, que se tornaram espécie de OSC. A atuação de outras entidades, embora pudessem ocorrer na prática, sob o amplo aspecto do convênio, agora possuem regramento específico.

A legislação passa a estar em consonância com o atual entendimento jurisprudencial sobre a cooperação público-privada em prol do interesse público. O Supremo Tribunal Federal (STF), no julgamento da ADI $n^{\circ} 1.923$, manifestou-se no sentido de que é possível a celebração de parcerias para consecução de serviços públicos, e de que o regime jurídico dessas parcerias permite a utilização de recursos públicos de forma peculiar, observando-se os princípios da Administração Pública, mas não retirando a flexibilidade da iniciativa privada (AKEMI, 2015).

Vislumbra-se que a nova lei, fruto de investigações sobre a malversação de recursos públicos, está em consonância com a interpretação do STF à Constituição. A padronização de procedimentos para celebração de parcerias entre a Administração Pública e o terceiro setor, da escolha do parceiro à prestação de contas, busca conciliar a opção ideológica de um Estado que utiliza a cooperação da iniciativa privada para atingir suas finalidades, sem descurar com o cuidado no uso dos recursos públicos.

\footnotetext{
${ }^{2}$ ONG é a denominação usual e não jurídica das entidades do 3o Setor (TOLEDO JUNIOR, 2015).
} 
Resta compreender qual a abrangência da uniformização procedimental trazida pelo novo marco. Apenas a União será objeto da norma ou os demais entes federativos também devem obedecê-la? Há espaço para os demais entes federativos desenvolverem regras próprias ou complementares ao regime da União?

\section{COMPETENCIA NORMATIVA PARA REGULAMENTAR AS PARCERIAS COM AS ORGANIZAÇÕES DA SOCIEDADE CIVIL}

O art. 22, inc. XXVII, da Constituição afirma que a elaboração de normas gerais sobre licitações e contratos pertencem à competência privativa da União. Editada norma geral, os demais entes federativos possuem tão somente competência residual sobre a matéria. Como bem pontua MEDAUR (2015, p. 218), “[...] O problema está na separação precisa entre normas gerais e normas específicas." Outro problema que também tem sido objeto de divergência entre os pesquisadores do Direito é se o dispositivo abrange as parcerias entre a Administração Pública e o terceiro setor.

Fora dos estritos limites do inc. XXVII, as normas que envolvem licitações e contratos administrativos são de Direito Administrativo, cabendo a cada ente legislar dentro de sua esfera de competência, respeitadas as normas gerais a que alude a Norma Superior (MELLO, 2015). A autonomia de cada ente federado para tratar dos ajustes que lhe dizem respeito decorre da descentralização federativa prevista no art. 18 da Constituição (RIBEIRO, 2015).

Desse arcabouço de competências decorre a conclusão de que nas licitações os entes federativos podem produzir normas específicas para atender suas particularidades, mas devem aplicar a Lei $n^{\circ} 8.666 / 1993^{3}$ (NOHARA, 2015). Mello (2015, p. 543) destaca ainda que “[...] a Lei 8.666, conforme estabelecem seu art. $1^{\circ}$ e parágrafo único, pretende ser impositiva não só para quaisquer Poderes da União, mas também para os Estados, Distrito Federal e Municípios, como se tudo que dela constasse tivesse o caráter de 'normas gerais'."

$\mathrm{Na}$ prática, existem diversa leis sobre licitações e contratos, pois vários entes federativos editaram seus próprios estatutos, como, por exemplo, a Lei Estadual $\mathrm{n}^{\mathbf{0}}$ 15.608/2007, que disciplina as licitações no âmbito do Estado do Paraná. Embora contenham disposições gerais, Medauar (2015, p. 218) esclarece que "De regra, Estados e Municípios ou editam leis sem dispositivos que contrariem a lei da União ou não editam lei específica e pautam suas licitações por aquela.” É o caso da Lei de Licitações Paranaense, cujo teor em muito se assemelha à norma geral federal.

Revista de Direito Administrativo e Gestão Pública | e-ISSN: 2526-0073 | Brasília | v. 2 | n. 1 | p. 227 - 245 | Jan/Jun. 2016. 
Não existe um consenso ou clareza do que são normas gerais. Mas se depreende que são aquelas que buscam uma padronização mínima dos regimes licitatórios e dos contratos. Portanto, versariam sobre requisitos mínimos para os procedimentos licitatórios e para a contratação, hipóteses de obrigatoriedade ou de não obrigatoriedade do processo seletivo, modalidades e tipos de licitação e o regime jurídico da contratação (JUSTEN FILHO, 2014).

Verifica-se, desse modo, que naquilo que possa ser considerada geral, a Lei $\mathrm{n}^{\circ}$ 13.019/2014 vincularia todos os entes federativos, cuja liberdade legislativa estaria restrita à sua complementação. Todavia, poderia a União editar as regras gerais sobre as parcerias de todos os entes federativos?

Para Moreira Neto (2014), os acordos sem natureza contratual não pertencem à competência legislativa privativa da União de que trata o art. 22, inc. XXVII, da Constituição. O art. 116 da Lei ${ }^{\circ}$ 8.666/1993, que determina a aplicação aos convênios das mesmas regras dos procedimentos licitatórios, não se aplicaria aos Estados e Municípios, competentes para traçar seus próprios regramentos sobre as parcerias.

Por conseguinte, os demais entes federativos só aplicariam as regras da Lei Federal de Licitações aos seus convênios se existissem normas, de sua competência, com dispositivo semelhante ao art. 116. É o caso do Estado do Paraná, cuja Lei Estadual nº 15.608/2007, embora traga regulamentações específicas para seus convênios, determina a aplicação das regras gerais dos contratos (art. 146).

Corroborando a posição de Moreira Neto, Ribeiro (2015) lembra que os convênios são expressamente mencionados na Constituição, a teor do art. 241, e não poderiam ser confundidos com os contratos administrativos mencionados no art. 22. Nesse caso a competência legislativa deveria observar as regras do art. 23, parágrafo único, o qual exige que as normas gerais sejam fixadas pela União através de Lei Complementar, o que não é o caso do novo marco das parcerias.

Os contratos administrativos, sujeitos a interesses opostos das partes expressados por contraprestação, não se confundiriam com a definição dos convênios utilizados nas parcerias. Nestes, como já mencionado, os interesses são paralelos e inexistem obrigações recíprocas.

Se se considerar que a Constituição diferenciou convênios de contratos, faltaria à União fundamento para estabelecer as normas gerais sobre as parcerias dos Estados e Municípios (FORTINI e PIRES, 2015). Oliveira (2015, p. 199-200) sintetiza essa posição:

\footnotetext{
${ }^{3}$ A Lei no 8.666/1993 é a norma geral sobre licitações e contratos pela Administração Pública (Art. 1ํ).
} 
Não obstante os inúmeros avanços da nova Lei, sustentamos a ausência de competência da União para impor normas gerais sobre o tema, aplicável aos Estados, Distrito Federal, Municípios e respectivas entidades da Administração Indireta.

$[\ldots]$

É forçoso concluir que a Constituição apenas estabelece a competência da União para elaborar normas gerais sobre contratos, na forma do art. 22, XXVII, da CRFB, inexistindo idêntica autorização em relação aos convênios. Em consequência, ausente norma constitucional que contemple a prerrogativa de fixação de normas gerais, por parte da União, para os convênios, a conclusão é no sentido de reconhecer a autonomia federativa dos entes para estabelecerem as suas próprias normas, na forma do art. 18 da CRFB. [...]

Por outro lado, Carvalho Filho (2014) esclarece que os operadores do direito não podem aplicar uma interpretação puramente literal ao art. 22, inc. XXVII, da Constituição. O intuito da norma foi imprimir aos termos contratação e licitação um sentido geral. Contratação abrangeria todos os ajustes que se assemelhariam aos acordos bilaterais de vontade, enquanto licitação abrangeria os processos seletivos de escolha da Administração para celebrar tais negócios jurídicos.

Justen Filho (2014b), que também reconhece a natureza contratual do convênio, vai além, defendendo que a competência da União para editar normas gerais sobre parcerias ou decorre do inc. XXVII do art. 22 ou do art. 24. Na mesma esteira, di Pietro (2015, p. 302) reforça a existência do gênero contrato, "acordo de vontades gerador de direitos e obrigações recíprocos", dentro do qual estariam os contratos administrativos em sentido estrito e as parcerias celebradas através de convênios.

Nas parcerias do Estado com o terceiro setor as principais diferenciações apontadas pela doutrina entre contratos e convênios, como inexistência de obrigações recíprocas, possibilidade de denunciação a qualquer tempo e sem punição e interesses paralelos e convergentes, não se aplicam. Há ingerência do Estado nos particulares, possibilidade de aplicação de sanções e até a impossibilidade de rescisão unilateral do acordo (RESENDE, 2014). Esse tratamento diferenciado é necessário para garantir o bom uso dos recursos públicos e a consecução das finalidades públicas almejadas. A caracterização usualmente atribuída aos convênios é direcionada àqueles celebrados entre órgãos administrativos, cujo respeito ao interesse público é inerente aos seus atos.

Revista de Direito Administrativo e Gestão Pública | e-ISSN: 2526-0073 | Brasília | v. 2 | n. 1 | p. 227 - 245 | Jan/Jun. 2016. 
Como bem pontuam Fortini e Pires (2015), o art. 241 da Constituição trata dos convênios público-público, mas existem os convênios público-privados, carregados de características próprias. Estes acordos eram tratados genericamente de convênios, e estavam submetidos às regras da Lei $\mathrm{n}^{\circ}$ 8.666/1993 por força de seu art. 116. Agora, são regulamentados pela Lei $n^{\circ} 13.019 / 2014$, cuja diretriz geral é o controle de resultados, mas ainda se preocupa com o controle de meios (SCHIEFLER, 2014).

Se, a partir da década de 1990, houve uma opção ideológica de incentivo às parcerias com entidades do terceiro setor, justificada por uma suposta eficiência da iniciativa privada em atingir o interesse público, não é possível pensar que a Administração Pública se eximiu do controle de meios e de resultados da atuação do particular, especialmente quando seu papel de financiador permanece. Como afirma Reis (2013, p. 163)

Por conseguinte, encerra-se com a certeza de que uma regulação, normatização e fiscalização sobre as entidades de colaboração, e também de cooperação, com a Administração Pública é inexorável para uma maior segurança dos gestores e administradores de tais entidades e do próprio resguardo do interesse público.

Refuta-se, portanto, a opinião de Oliveira (2014, p. 13) de que "Em síntese, é possível concluir que a Lei ${ }^{\circ} 13.019 / 2014$ deve ser interpretada em conformidade com a Constituição para ser considerada, em princípio, lei federal (e não nacional) aplicável à União". Não parece que o legislador constituinte procurou imprimir uma acepção restritiva ao termo contrato, submetendo as empresas públicas e as sociedades de economia mista a regras licitatórias, mas excluindo as escolhas da Administração Direta e sua fiscalização sobre o gasto dos recursos públicos pelos parceiros privados. Como pontua Justen Filho (2014, p. 39):

O convênio administrativo se caracteriza como um contrato de cunho organizacional, destituído de finalidade lucrativa, por meio do qual duas ou mais partes, sendo pelo menos uma delas integrantes da Administração Pública, obrigam-se a conjugar recursos e esforços para desempenhar atividade de interesse coletivo $[\ldots]$

Imaginar que a Constituição atribuiu à União competência privativa para legislar sobre as normas gerais de contratos, mas delegou aos demais entes federativos competência plena 
sobre as parcerias com o terceiro setor, fruto de uma opção ideológica neoliberal imprimida à Administração Pública a partir da década de 1990, não protege o interesse público. Mais que isso, apega-se a classificações e distinções doutrinárias para diferenciar a atuação direta do Estado, submetida à padronização pela União, com sua atuação por terceiros, que estariam sujeitas a regimes diversos, conforme regulamentação de cada ente federativo.

Não há manifestação expressa do Supremo Tribunal Federal sobre o assunto. Todavia, decidindo na $\mathrm{ADI} \mathrm{n}^{\circ} 1.923$ que os princípios da Administração devem ser respeitados pelo Estado ao formular parcerias com as OS, a Corte Constitucional sinaliza ao intérprete que deve ser empregada a solução que proporcione melhor segurança jurídica ao administrador e ao particular: a padronização através de um regime jurídico único, extraído de normas gerais editadas pela União. Portanto, a Lei nº13.019/2014 merece ser interpretada como lei nacional, cujas regras gerais devem ser observadas por todos entes federativos.

\section{APLICAÇÃO DA LEI N 13.019/2014 NO ESTADO DO PARANÁ}

No Estado do Paraná as licitações e contratos foram regulamentadas pela Lei Estadual $\mathrm{n}^{\mathrm{o}} 15.608 / 2007$, estatuto de 169 artigos que disciplinou as regras do procedimento licitatório, das contratações e das parcerias pelo ente federativo estadual. Embora possua regras gerais e específicas, sua (in)constitucionalidade ainda não foi objeto de decisão específica do Supremo Tribunal Federal.

Por repetir as regras gerais da Lei Federal de Licitações, a Lei Estadual acabou respeitando a competência constitucional do inc. XXVII do art. 22. Questão que aguarda decisão da Corte Constitucional, a previsão de que as fases de habilitação dos licitantes e de julgamento das propostas ocorram em ordem inversa à prevista nacionalmente tem sido considerada matéria específica pela doutrina, que defende sua constitucionalidade (HOLTHE, 2014).

Até a entrada em vigor da Lei $n^{\circ} 13.019 / 2014$, a Lei Estadual $n^{\circ} 15.608 / 2007$ estabelecia as regras sobre as parcerias a serem firmadas pelo Estado do Paraná. A própria norma define de forma abrangente convênio como "acordo, ajuste ou instrumento congênere firmado por entidades públicas entre si ou com particulares, em que haja um acordo de vontades para a formação de vínculo e a estipulação de obrigações recíprocas, seja qual for a denominação utilizada" (inc. XII do art. $4^{\circ}$ ).

Revista de Direito Administrativo e Gestão Pública | e-ISSN: 2526-0073 | Brasília | v. 2 | n. 1 | p. 227 - 245 | Jan/Jun. 2016. 
Entre os art. 133 e 145 a norma limita o conceito de convênio, traça requisitos para o instrumento e seu plano de trabalho e traz hipóteses de vedação, de alteração do objeto e de extinção. Para finalizar, o art. 146, cujo teor é semelhante ao art. 116 da Lei $n^{\circ}$ 8.666/1993, determina a aplicação, no que couber, das demais disposições da lei às parcerias celebradas.

No âmbito paranaense, portanto, a disciplina dos convênios recebeu tratamento legal mais detalhado que na esfera federal. Enquanto a União optou por regulamentar a legislação licitatória através de decretos e portarias, o Estado do Paraná estabeleceu requisitos específicos no próprio texto legal.

Pois bem, as disposições da Lei Estadual nº15.608/2007 se aplicam às parcerias com as OSC?

O novo marco das parcerias dispôs sobre o art. 116 da Lei ${ }^{\circ}$ 8.666/1993, norma que 
só permanecerá válida para as hipóteses ali descritas:

Art. 84. Não se aplica às parcerias regidas por esta Lei o disposto na Lei ${ }^{\circ}$ 8.666, de 21 de junho de 1993.

Parágrafo único. São regidos pelo art. 116 da Lei $n^{\circ}$ 8.666, de 21 de junho de 1993, convênios:

I - entre entes federados ou pessoas jurídicas a eles vinculadas

II - decorrentes da aplicação do disposto no inciso IV do art. 30.

Art. 84-A. A partir da vigência desta Lei, somente serão celebrados convênios nas hipóteses do parágrafo único do art. 84.

Seguindo o entendimento de que a Lei $\mathrm{n}^{\circ}$ 13.019/2014 é uma norma nacional, oriunda da competência privativa da União para legislar sobre as normas gerais de licitações e contratos (art. 22, inc. XXVII), caberiam aos Estados e Municípios legislar sobre as particularidades de sua aplicação. As especificidades e regulamentações que já existiam para as parcerias com o terceiro setor, antes formalizadas mediante convênio, permanecem válidas naquilo que não contrariarem a norma geral.

No Estado do Paraná, todavia, a Lei no 13.019/2014 foi regulamentada através do Decreto Estadual $n^{\mathrm{o}} 3.513 / 2016$, conforme afirma seu art. $1^{\mathrm{o}}$ :

Art. 1. ${ }^{\circ}$ Fica regulamentada as normas gerais para as parcerias entre a administração pública do Estado do Paraná e organizações da sociedade civil, em regime de mútua cooperação, para a consecução de finalidades e interesse público e recíproco, mediante a execução de atividades de projetos previamente estabelecidos em planos de trabalho inseridos em termos de colaboração, em termos de fomento ou em acordos de cooperação, de que trata a Lei Federal n. ${ }^{\circ}$ 13.019, de 31 de julho de 2014.

Embora a Lei Estadual $n^{\circ} 15.608 / 2007$ trate do tema, as normas gerais instituídas pelo novo marco das parcerias foram regulamentadas através de decreto, que não menciona a sistemática vigente. Ainda, determina em seu art. 91 que a Lei $n^{\circ}$ 13.019/2014 aplica-se subsidiariamente ao teor do decreto.

A única interpretação possível da regulamentação do decreto estadual é de que sua abrangência é apenas das normas gerais sobre as parcerias com o terceiro setor, não esgotando a matéria. Ou seja, permanecem válidas as normas que tratem de especificidades quando da 
aplicação do novo marco no âmbito estadual, desde que não contrarie as regras gerais. Permanecem válidas, até que haja nova regulamentação legal, as disposições da Lei Estadual $\mathrm{n}^{\mathrm{o}} 15.608 / 2007$ que tratavam sobre as parcerias com as OSC, então revestidas sob a forma genérica de convênio.

Continuarão existindo as controvérsias e incertezas que atingiam a aplicação da Lei no 8.666/1993 e as normas estaduais e municipais de licitações e contratos. Todavia, os art. 84 e 84-A da Lei $\mathrm{n}^{\mathrm{o}}$ 13.019/2014 afastam apenas a aplicação da Lei Federal de Licitações, permanecendo válidas as normas específicas que regulamentavam as parcerias entre o Poder Público e o terceiro setor nos Estados e Municípios, antes do novo marco e até que ulterior legislação as revogue expressamente.

\section{CONCLUSÃO}

As parcerias entre o Poder Público e o terceiro setor decorrem de opção ideológica dos administradores públicos a partir da década de 1990. Para que as parcerias se mantenham legítimas, é preciso que haja segurança jurídica na relação público-privada, com regras claras definindo o âmbito de aplicação de cada novo instrumento criado.

O Supremo Tribunal Federal, no julgamento da ADI $\mathrm{n}^{\circ} 1.923$, considerou constitucional a opção do Estado de perseguir o interesse público em cooperação com a iniciativa privada, desde que observados os princípios da Administração Pública. Portanto, o Estado deve manter o controle das políticas públicas e da utilização de recursos públicos, ainda que a execução ocorra através da iniciativa privada e de seu regime jurídico mais flexível.

Até a edição da Lei $\mathrm{n}^{\circ}$ 13.019/2014 as parcerias com o terceiro setor eram instrumentalizadas através de convênio. A nova lei regulamentou uma parcela dessas parcerias, submetendo as OSC à formalização de termos de fomento ou de cooperação.

Para alcançar a padronização procedimental e a consecução das finalidades públicas, deve prevalecer o entendimento de que o inc. XXVII do art. 22 da Constituição trata da competência privativa da União para legislar sobre as normas gerais sobre contratos em sentido amplo, incluídos os instrumentos de parceria do Poder Público. Logo, a Lei no 13.019/2014 é nacional.

Por ser norma geral, o novo marco das parcerias deve ser aplicado pelos Estados e Municípios brasileiros. Todavia, as normas específicas editadas por tais entes, para atender suas especificidades nos convênios, permanecem válidas naquilo que não contrariarem as novas 
regras gerais, e até que nova legislação as revogue expressamente. Não lhes serão aplicados, por mera simetria, o disposto nos art. 84 e 84-A da Lei $n^{\circ} 13.019 / 2014$, que afastam a Lei Federal de Licitações.

Desse modo, as leis estaduais e municipais de licitações e contratos, nos moldes da Lei Estadual $n^{\circ} 15.608 / 2007$, não tiveram seu âmbito de aplicação integralmente subtraídos pelo novo marco. Critérios, requisitos e meios de controle mais rígidos, vigentes nos Estados e Municípios, permanecerão resguardando o interesse público local, sendo aplicados em consonância com o novo marco até que sejam revogados.

\section{REFERÊNCIAS}

BELÉM, Bruno. Comentários ao Decreto nº.170, de 25 de julho de 2007 (art. $2^{\circ}$ ). Fórum Municipal \& Gestão das Cidades - FMGC, Belo Horizonte, ano 2, n. 6, p. 71-75, jul./ago. 2014.

CARVALHO FILHO, José dos Santos. Manual de direito administrativo. 25. ed. São Paulo: Atlas, 2012.

. O novo regime jurídico das parcerias voluntárias. Fórum de Contratação e Gestão Pública-FCGP, Belo Horizonte, ano 13, n. 155, p. 21-31, nov. 2014.

COPOLA, Gina. As parcerias celebradas entre a Administração Pública e as Organizações da Sociedade Civil: a improbidade administrativa (Lei Federal no 13.019, de 31 de julho de 2014). Fórum de Contratação e Gestão Pública - FCGP, Belo Horizonte, ano 13, n. 154, p. 9-18, out. 2014.

DI PIETRO, Maria Sylvia Zanella. Parcerias na administração pública: concessão, permissão, franquia, terceirização, parceria público-privada e outras formas. 9. ed. São Paulo: Atlas, 2012.

. Direito administrativo. 28. ed. São Paulo: Atlas, 2015.

FORTINI, Cristiana; PIRES, Priscila Giannetti Campos. O regime jurídico das Parcerias Voluntárias com as Organizações da Sociedade Civil: inovações da Lei n 13.019/2014. Revista de Direito Administrativo e Constitucional - A \& C, Belo Horizonte, ano 15, n. 61, p.93-116, jul./set. 2015.,

FREITAS, Aline Akemi. Os alicerces da nova Lei de Fomento e de Colaboração (Lei $\mathrm{n}^{\circ}$ 13.019/2014): para um controle por resultado. R. Dir. Terc. Setor - RDTS, Belo Horizonte, ano 9, n. 17, p. 11-36, jan./jun. 2015.

GARCIA, Ana Carolina Ramos; CASTRO, Camila Crespi. Lei federal nº13.019/14 (parcerias voluntárias) e Anteprojeto de Nova Lei Orgânica da Aministração Pública do Ministério do Planejamento, Orçamento e Gestão: tendências de normatização da matéria de parcerias do

Revista de Direito Administrativo e Gestão Pública | e-ISSN: 2526-0073 | Brasília | v. 2 | n. 1 | p. 227 - 245 | Jan/Jun. 2016. 
Estado com o Terceiro Setor no Brasil: considerações de lege lata e lege ferenda. R. Dir. Terc. Setor - RDTS, Belo Horizonte, ano 8, n. 16, p. 61-76, jul./dez. 2014.

GUERRA, Evandro Martins; GUERRA, Gabriela de Moura e Castro. O novo Marco Regulatório das Organizações da Sociedade Civil. Fórum Administrativo - FA, Belo Horizonte, ano 15, n. 176, p. 48-53, out. 2015.

JUSTEN FILHO, Marçal. Comentários à lei de licitações e contratos administrativos: lei 8.666/1993. 16. ed., rev., atual., e ampl. São Paulo: Revista dos Tribunais, 2014.

. Curso de direito administrativo. 11. ed., rev., atual., e ampl. São Paulo: Revista dos Tribunais, 2015.

MARTINS, Denis Monassa; SILVA, Rodrigo Crelier Zambão. O papel dos controles internos para garantia da probidade na gestão pública: uma análise prática de convênios. Fórum de Contratação e Gestão Pública - FCGP, Belo Horizonte, ano 13, n. 155, p. 9-20, nov. 2014.

MARTINS, Silvia Portes Rocha. O novo marco regulatório das parcerias voluntárias Modificações trazidas pela Lei ${ }^{\circ}$ 13.019/2014. Fórum Administrativo-FA, Belo Horizonte, ano 15, n. 173, p. 52-61, jul. 2015.

MEDAUAR, Odete. Direito administrativo moderno. 19. ed., rev. e atual. São Paulo: Revista dos Tribunais, 2015.

MELLO, Celso Antônio Bandeira de. Curso de direito administrativo. 32. ed. São Paulo: Malheiros, 2015.

NOHARA, Irene Patrícia. Direito administrativo esquematizado. 5. ed., atual. e rev. São Paulo: Atlas, 2015.

OLIVEIRA, Rafael Carvalho Rezende. Curso de direito administrativo. 3. ed., rev., atual. e ampl. São Paulo: Método, 2015.

. O novo marco regulatório das parcerias entre a Administração e as organizações da sociedade civil: aspectos relevantes da Lei $\mathrm{n}^{\circ}$ 13.019/2014. R. bras. de Dir. Público RBDP, Belo Horizonte, ano 12, n. 46, p. 9-32, jul./set. 2014.

REIS, Luciano Elias. Convênio administrativo: instrumento jurídico eficiente para o fomento e desenvolvimento do Estado. Curitiba: Juruá, 2013.

RESENDE, Mariana Bueno. Convênios administrativos - Análise acerca da obrigatoriedade do vínculo jurídico. R. Proc-geral Mun. Belo Horizonte - RPGMBH, Belo Horizonte, ano 6, n. 12, p. 131-149, jul./dez. 2014.

RIBEIRO, Leonardo Coelho. O novo marco regulatório do Terceiro Setor e a disciplina das parcerias entre Organizações da Sociedade Civil e o Poder Público. R. bras. de Dir. Público - RBDP, Belo Horizonte, ano 13, n. 50, p. 95-110, jul./set. 2015. 
SANTOS, Lenir. Serviços privados no SUS: o regime de complementariedade dos serviços públicos de saúde e a Lei no 13019 de 2014. R. bras. de Dir. Público - RBDP, Belo Horizonte, ano 13, n. 49, p. 9-26, abr./jun. 2015.

SOUSA, Otavio Augusto Venturini. Parcerias com o terceiro setor no Brasil: evolução e aspectos críticos nos últimos 20 anos. R. bras. de Est. da Função públ. - RBEFP, Belo Horizonte, ano 4, n. 12, p. 151-161, set./dez. 2015.

SCHIEFLER, Gustavo Henrique Carvalho. Comentários a convivência do controle de resultados e de meios nas parcerias voluntárias: uma análise a partir da Lei Deferal $\mathrm{n}^{\circ} 13$. 19/2014. R. Dir. Terc. Setor - RDTS, Belo Horizonte, ano 8, n. 16, p. 123-135, jul./dez. 2014.

TOLEDO JUNIOR, Flavio Corrêa. O marco regulatório das Organizações da Sociedade Civil e o alcance dos auxílios e subvenções. Fórum Administrativo - FA, Belo Horizonte, ano 15, n. 174 , p. 34-38, ago. 2015.

VAN HOLTHE, Leo Oliveira. Limites da competência estadual para legislar sobre licitações e contratos. Rev. Estudos Legislativos, Porto Alegre, ano 8, n. 8, p. 11-41, 2014.

VIOLIN, Tarso Cabral. Uma análise crítica do ideário do 'terceiro setor' no contexto neoliberal e as parcerias com a Administração Pública. Revista IOB de Direito Administrativo, São Paulo, v.3, n.27, p. 61-72, mar. 2008. 